\title{
Respiratory Distress and Its Outcome among Neonates Admitted to Neonatal Intensive Care Unit of Mukalla Maternity and Child Hospital, Yemen
}

Saleh Awad Bahwal (MD,MSc) ${ }^{1}$, Mazin Ahmed Jawass (MD,MSc) ${ }^{2}$ and Ali Salim

Bahartha (JBP, MBBS $)^{3}$

\begin{abstract}
Background: Respiratory distress is one of the most common causes of admission in neonatal intensive care unit .

Objective: To determine the causes and to study the various risk factors associated with development of respiratory distress and outcomes of respiratory distress in neonates admitted to neonatal care unit of Mukalla Maternity and Child Hospital in Al- Mukalla city, Hadhramaut Governorate, Yemen.

Patients and Methods: This is a prospective study covering the 12-month period between April 2018 to March 2019 to neonates admitted to neonatal care unit of Mukalla MaternityandChild hospital.

Results: A total of 430 patients were admitted to the neonatal care unit. Number of cases presented with respiratory distress was 250 , representing $58.1 \%$ of all cases admitted. The most frequent underlying cause for respiratory distress in children was respiratory distress syndrome (44\%), followed by transient tachypnea of the newborn (18.8\%), birth asphyxia (14\%), meconium aspiration syndrome (12\%), and other causes (11.2) (CHD 10(4\%), sepsis (3.2\%), congenital pneumonia (2.4\%), and congenital anomalies (1.6\%). The majority of cases of respiratory distress syndrome and transient tachypnea of newborn were males with statistical significant difference. The outcome of neonatal respiratory disorders was: cure in $40.4 \%$ of cases, patients discharged with complications in $10.4 \%$ of cases, and death in $49.2 \%$ of cases. The highest case fatality rate of neonatal respiratory distress diseases were respiratory distress syndrome $(81.8 \%)$ followed by meconium aspiration syndrome $(56.7 \%)$ and birth asphyxia $(34.3 \%)$.
\end{abstract}

Conclusion: Respiratory distress syndrome was the main cause of respiratory distress followed by transient tachypnea of newborn.

Keywords:Respiratory distress, neonate, causes, outcome, risk factor, NICU.

Corresponding Author: dr.salehbahwal@yahoo.com

Received: $15^{\text {th }}$ September 2019

Accepted: $10^{\text {th }}$ October 2019

DOI:https://doi.org/10.26505/DJM.18014940915

${ }^{1,2,3}$ College of Medicine- Hadhramout University- Al-Mukalla-Hadhramout-Yemen. 


\section{Introduction}

Respiratory distress (RD) is a challenging problem and is one of the most common causes of admission in neonatal intensive care unit (NICU) [1]. Respiratory distress is reported in 13.3- 88\% of ill neonates [2-7]. A wide variety of pathologic lesions may be responsible for respiratory disturbances, including pulmonary, airway, cardiovascular, central nervous, infection, and other disorders [8]. Some risk factors increase the likelihood of neonatal respiratory disease; prematurity, meconium stained amniotic fluid, cesarean delivery, gestational diabetes, maternal chorioamnionitis and presence of prenatal ultrasonographic findings such as oligohydramnios or structural lung abnormalities [9]. Irrespective of the underlying etiology, neonatal respiratory diseases NRD has been reported to contribute to poor neonatal outcomes particularly in the developing countries [6,10]. Therefore, any healthcare professional who cares for newborn babies should easily recognize the symptoms and signs of respiratory distress, distinguish between various causes and initiate management strategies to prevent significant complications or death [11]. The aim of this study was to determine the causes and to study the various risk factors associated with development of $\mathrm{RD}$ and outcomes of respiratory distress in neonates admitted to NICU of Mukalla Maternity and Child Hospital (MMCH).

\section{Patients and Methods}

This is a prospective study covering the 12month period between April 2018 to March 2019 to neonates admitted to NICU of
MMCH in Al- Mukalla city, Hadhramaut Governorate, Yemen. Out of 430 neonates admitted to NICU of MMCH during study period 250 of them had RD which constituted $58.1 \%$ of all cases admitted.

Inclusion criteria: Were all neonate admitted to NICU in MMCH with a diagnosis of NRD. Exclusion criteria: Babies weight less than 1000 gms and babies less than 28 wks of age were excluded from the study. The following information's were recorded: The maternal data included: maternal age at pregnancy, parity, maternal hypertension, maternal diabetic, multiple gestation, antepartum hemorrhage, maternal fetal infection, Pre-eclampsia, mode of delivery, prolonged labor. Neonatal data included : Gender, gestational age, birth weight.

\section{Definition of terms}

Neonatal respiratory distress: The presence of one or more of the following signs: tachypnea > 60 breaths/min, or signs of labored breathing (expiratory grunting, nasal flaring, intercostal recessions, xyphoid recessions, or thoraco-abdominal asynchrony), with or without cyanosis [4].Diagnostic criteria for RDS were considered by the presence of clinical sign, such as grunting, flaring, tachypnea, retractions, requiring a respiratory support (supplemental oxygen requirement and/or non-invasive or invasive ventilation). Typical radiological findings were reticulogranular patterns, air bronchograms and ground glass appearance [12]. Transient tachypnea of newborn (TTN) is characterized by the early 
Respiratory Distress and Its Outcome among Neonates Admitted to Neonatal Intensive Care Unit of

Mukalla Maternity and Child Hospital, Yemen

onset of tachypnea (>60 breaths/min), sometimes with retractions or expiratory grunting and occasionally with cyanosis that is relieved by minimal $\mathrm{O} 2$ supplementation $(<40 \%)$. The chest generally sounds clear without crackles or wheeze, and the chest radiograph shows prominent perihilar pulmonary vascular markings, fluid in the intralobar fissures, and rarely small pleural effusions [13].

Birth asphyxia was presumed in outborns when there was a history that the baby had failed to cry or breathe at birth [14]. Apgar score was used in all inborn; a score $<7$ in the first minute and fifth minute was regarded as asphyxia [14].

Meconium aspiration syndrome was defined as the onset of respiratory distress after birth with meconium-stained body and liquor with or without features of air leaks[15] Chest radiograph may show widespread patchy or homogenous opacities infiltrates and evidence of air trapping[15]. Diagnosis of sepsis was made when the baby had a bacterial growth on blood culture or cerebrospinal fluid culture, respectively [16]. Case Fatality Rate (CFR) $=$ (No. of deaths due to certain disease/ Total cases from that disease) x100 [17].

\section{Statistical analysis}

The collected data were coded, tabulated, and statistically analyzed using SPSS program and version 17. Data were described using frequencies and percentages. The differences between proportions were tested using chi-square test. A p-value less than 0.05 was considered statistically significant.

\section{Results}

From April 2018 to March 2019, a total of 430 patients were admitted to the NICU. Number of cases presented with respiratory distress was 250 , representing $58.1 \%$ of all cases admitted. Due to the small percentage of congenital heart disease, congenital anomalies, congenital pneumonia, sepsis, they were combined as the term of others for subsequent analysis.

Table (1) illustrates that babies delivered by CS showed significantly high rates of both RDS and TTN when compared to delivered by vaginal delivery. Prolonged labor were significantly associated with TTN, BA and MAS. None of the other maternal characteristics were associated with causes of NRD.

Table (2) illustrates no significant association between maternal hypertension, maternal diabetes, multiple gestation and causes of NRD.

Table (3) shows no significant association between antepartum hemorrhage, maternal fetal infection, pre-eclampsia and causes of NRD.

Table (4) illustrates that the majority of cases of RDS and TTN were male with statistical significant difference. The only neonatal RD disorders that were associated with low birth weight was RDS. It was found that RDS was significantly associated with prematurity, while TTN and MAS were significantly associated with full term.

Table(5) shows the highest case fatality rate of neonatal respiratory distress diseases were RDS (81.8\%) followed by MAS 
Respiratory Distress and Its Outcome among Neonates Admitted to Neonatal Intensive Care Unit of

Mukalla Maternity and Child Hospital, Yemen

$(56.7 \%), \quad$ BA $\quad(34.3 \%)$, congenital anomalies(25\%), CHD (20\%) and neonatal sepsis(12.5).

Table (6) summarizes the underlying illnesses of NRD in this study, compared with results from previous studies.

Figure(1) summarizes the most frequent underlying causes for NRD were respiratory distress syndrome(RDS)110(44\%), followed

Table (1): Relationship of maternal age, parity, mode of delivery, prolonged labor and causes of NRD

\begin{tabular}{|c|c|c|c|c|c|}
\hline \multirow[b]{2}{*}{ Causes of RD } & \multirow{2}{*}{$\begin{array}{c}\text { Total } \\
(\mathrm{N}=250)\end{array}$} & \multicolumn{3}{|c|}{$\begin{array}{l}\text { Maternal age (year) } \\
\end{array}$} & \multirow[t]{2}{*}{ P-value } \\
\hline & & \multicolumn{2}{|l|}{$\begin{array}{l}<35(200) \\
\mathrm{N}(\%)\end{array}$} & $\begin{array}{c}>35(50) \\
N(\%)\end{array}$ & \\
\hline RDS & 110 & \multicolumn{2}{|l|}{$90(81.8)$} & $20(18.2)$ & 0.52 \\
\hline TTN & 447 & \multicolumn{2}{|l|}{$36(76.6)$} & $811(23.4)$ & 0.51 \\
\hline BA & 35 & \multicolumn{2}{|l|}{$30(85.7)$} & $5(14.3)$ & 0.36 \\
\hline MAS & 30 & \multicolumn{2}{|l|}{$23(76.7)$} & $7(23.3)$ & 0.62 \\
\hline Others & 28 & $21(75)$ & & $7(25)$ & 0.48 \\
\hline \multirow[b]{2}{*}{ Causes of RD } & \multirow[b]{2}{*}{$\begin{array}{c}\text { Total } \\
(\mathrm{N}=250)\end{array}$} & \multicolumn{3}{|c|}{ Parity } & \multirow[t]{2}{*}{ P-value } \\
\hline & & $\begin{array}{c}\text { Primiparous }(60) \mathrm{N} \\
(\%)\end{array}$ & $\begin{array}{l}1-2(100) \\
\mathrm{N}(\%)\end{array}$ & $\begin{array}{l}>3(90) \\
\mathrm{N}(\%)\end{array}$ & \\
\hline RDS & 110 & $30(27.3)$ & $45(40.9)$ & $35(31.8)$ & 0.28 \\
\hline TTN & 47 & $14(29.8)$ & $17(36.2)$ & $16(34)$ & 0.30 \\
\hline $\mathrm{BA}$ & 35 & $8(22.8)$ & $12(34.3)$ & $15(42.9)$ & 0.86 \\
\hline MAS & 30 & $4(13.3)$ & $17(56.7)$ & $9(30)$ & 0.15 \\
\hline Others & 28 & $4(14.3)$ & $9(32.1)$ & $15(53.6)$ & 0.20 \\
\hline \multirow[b]{2}{*}{ Causes of RD } & \multirow{2}{*}{$\begin{array}{c}\text { Total } \\
(\mathrm{N}=250)\end{array}$} & \multicolumn{3}{|c|}{ Mode of delivery } & \multirow[t]{2}{*}{ P-value } \\
\hline & & $\begin{array}{l}\text { Vaginal delivery (73) } \\
\mathrm{N}(\%)\end{array}$ & \multicolumn{2}{|c|}{\begin{tabular}{|c} 
Cesarean delivery (177) \\
$\mathrm{N}(\%)$
\end{tabular}} & \\
\hline RDS & 110 & $25(22.7)$ & \multicolumn{2}{|c|}{$\begin{array}{l}85(77.3) \\
\end{array}$} & 0.04 \\
\hline TTN & 47 & $20(42.6)$ & \multicolumn{2}{|r|}{$27(57.4)$} & 0.02 \\
\hline $\mathrm{BA}$ & 35 & $15(42.9)$ & \multicolumn{2}{|r|}{$20(57.1)$} & 0.05 \\
\hline MAS & 30 & $5(16.7)$ & & $25(83.3)$ & 0.11 \\
\hline Others & 28 & $8(28.6)$ & & $20(71.4)$ & 0.93 \\
\hline & Total & & longed labc & & P-value \\
\hline Causes of RD & $(\mathrm{N}=250)$ & $\begin{array}{l}\text { Yes (175) } \\
\mathrm{N}(\%)\end{array}$ & & $\begin{array}{l}\text { No (75) } \\
\mathrm{N}(\%)\end{array}$ & \\
\hline RDS & 110 & $74(67.3)$ & & $36(32.7)$ & 0.40 \\
\hline TTN & 47 & $25(53.2)$ & & $22(46.8)$ & 0.006 \\
\hline $\mathrm{BA}$ & 35 & $30(85.7)$ & & $5(14.3)$ & 0.03 \\
\hline MAS & 30 & $26(86.7)$ & & $4(13.3)$ & 0.04 \\
\hline Others* & 28 & $20(71.4)$ & & $8(28.6)$ & 0.86 \\
\hline
\end{tabular}
47(18.8\%), birth asphyxia (BA) 35(14\%), meconium aspiration syndrome (MAS)12(12\%), others 28(11.2).

Figure(2) shows that the outcome of NRD was: cure in $40.4 \%$ of cases, patients discharged with complications in 10.4 of cases, and death in $49.2 \%$ of cases.

by transient tachypnea of the newborn (TTN) 
Respiratory Distress and Its Outcome among Neonates Admitted to Neonatal Intensive Care Unit of

Mukalla Maternity and Child Hospital, Yemen

*RDS : Respiratory distress syndrome

TTN : Transient tachypnea of newborn

**BA: Birth asphyxia

MAS : Meconium aspiration syndrome

Others (congenital heart disease, congenital pneumonia, sepsis and congenital anomalies)

Congenital anomalies(diaphragmatic hernias, tracheoesophageal fistula, congenital lobar emphysema)

Table (2): Relationship of maternal hypertension, maternal diabetes, multiple gestation and causes of NRD

\begin{tabular}{|c|c|c|c|c|}
\hline \multirow[t]{2}{*}{ Causes of RD } & \multirow{2}{*}{$\begin{array}{c}\text { Total } \\
(\mathrm{N}=250)\end{array}$} & \multicolumn{2}{|c|}{ Maternal hypertension } & \multirow[t]{2}{*}{ P-value } \\
\hline & & $\begin{array}{c}\text { Yes(15) } \\
\mathrm{N}(\%)\end{array}$ & $\begin{array}{c}\mathrm{No}(235) \\
\mathrm{N}(\%)\end{array}$ & \\
\hline RDS & 110 & $5(4.5)$ & $105(95.5)$ & 0.39 \\
\hline MAS & 47 & $3(6.4)$ & $44(93.6)$ & 0.90 \\
\hline $\mathrm{BA}$ & 35 & $2(5.7)$ & $33(94.3)$ & 0.93 \\
\hline MAS & 30 & $4(13.3)$ & $26(86.7)$ & 0.08 \\
\hline Others & 28 & $1(3.6)$ & $27(96.4)$ & 0.57 \\
\hline \multirow[t]{2}{*}{ Causes of RD } & \multirow{2}{*}{$\begin{array}{c}\text { Total } \\
(\mathrm{N}=250)\end{array}$} & \multicolumn{2}{|c|}{ Maternal diabetes } & \multirow[t]{2}{*}{ P-value } \\
\hline & & $\begin{array}{c}\text { Yes(10) } \\
\mathrm{N}(\%)\end{array}$ & $\begin{array}{c}\mathrm{No}(240) \\
\mathrm{N}(\%)\end{array}$ & \\
\hline RDS & 110 & $5(4.5)$ & $105(95.5)$ & 0.21 \\
\hline TTN & 47 & $1(2.1)$ & $46(97.9)$ & 0.58 \\
\hline $\mathrm{BA}$ & 35 & $0 .(0.0)$ & $35(100)$ & 0.42 \\
\hline MAS & 30 & $2(6.7)$ & $28(93.3)$ & 0.37 \\
\hline Others & 28 & $2(7.1)$ & $26(92.9)$ & 0.32 \\
\hline \multirow[t]{2}{*}{ Causes of RD } & \multirow{2}{*}{$\begin{array}{c}\text { Total } \\
(\mathrm{N}=250)\end{array}$} & \multicolumn{2}{|c|}{ Multiple gestation } & \multirow[t]{2}{*}{ P-value } \\
\hline & & $\begin{array}{l}\text { Yes (6) } \\
\mathrm{N}(\%)\end{array}$ & $\begin{array}{c}\mathrm{No}(244) \\
\mathrm{N}(\%)\end{array}$ & \\
\hline RDS & 110 & $3(2.7)$ & 107(97.3) & 0.76 \\
\hline TTN & 47 & $2(4.3)$ & $45(95.7)$ & 0.36 \\
\hline $\mathrm{BA}$ & 35 & $1(2.9)$ & $34(97.1)$ & 0.84 \\
\hline MAS & 30 & $0(0.0)$ & $30(100)$ & 0.67 \\
\hline Others & 28 & $0(00)$ & $28(100)$ & 0.71 \\
\hline
\end{tabular}

Table (3): Relationship of antepartum hemorrhage, maternal fetal infection, pre-eclampsia and causes of NRD

\begin{tabular}{|c|c|c|c|c|}
\hline \multirow[t]{2}{*}{ Causes of RD } & \multirow{2}{*}{$\begin{array}{c}\text { Total } \\
(\mathrm{N}=250)\end{array}$} & \multicolumn{2}{|c|}{ Antepartum hemorrhage } & \multirow[t]{2}{*}{ P-value } \\
\hline & & $\begin{array}{c}\text { Yes (18) } \\
\text { N (\%) }\end{array}$ & $\begin{array}{c}\mathrm{No}(232) \\
\mathrm{N}(\%)\end{array}$ & \\
\hline RDS & 110 & $8(7.3)$ & $102(92.7)$ & 0.96 \\
\hline TTN & 47 & $2(4.2)$ & $45(95.8)$ & 0.39 \\
\hline BA & 35 & $5(14.3)$ & $30(85.7)$ & 0.09 \\
\hline MAS & 30 & $3(10)$ & $27(90)$ & 0.52 \\
\hline Others & 28 & $0(00)$ & $28(100)$ & 0.25 \\
\hline \multirow[t]{2}{*}{ Causes of RD } & \multirow{2}{*}{$\begin{array}{c}\text { Total } \\
(\mathrm{N}=250)\end{array}$} & \multicolumn{2}{|c|}{ Maternal fetal infection } & P-value \\
\hline & & $\begin{array}{c}\text { Yes (15) } \\
\mathrm{N}(\%)\end{array}$ & $\begin{array}{l}\mathrm{N}(235) \\
\mathrm{N}(\%)\end{array}$ & \\
\hline RDS & 110 & $5(4.5)$ & $105(95.5)$ & 0.90 \\
\hline TTN & 47 & $3(6.4)$ & 44(93.6) & 0.72 \\
\hline
\end{tabular}


Respiratory Distress and Its Outcome among Neonates Admitted to Neonatal Intensive Care Unit of

\begin{tabular}{|c|c|c|c|c|}
\hline Birth asphyxia & 35 & $1(2.9)$ & $34(97.1)$ & 0.46 \\
\hline MAS & 30 & $3(10)$ & $27(90)$ & 0.28 \\
\hline Others & 28 & $3(10.7)$ & $25(89.3)$ & 0.23 \\
\hline \multirow[t]{2}{*}{ Causes of RD } & \multirow{2}{*}{$\begin{array}{c}\text { Total } \\
(\mathrm{N}=250)\end{array}$} & \multicolumn{2}{|c|}{ Pre-eclampsia } & P-value \\
\hline & & $\begin{array}{l}\text { Yes (6) } \\
\mathrm{N}(\%) \\
\end{array}$ & $\begin{array}{c}\mathrm{N}(244) \\
\mathrm{N}(\%) \\
\end{array}$ & \\
\hline RDS & 110 & $2(1.8)$ & $108(98.2)$ & 0.44 \\
\hline TTN & 47 & $0(0.0)$ & $47(100)$ & 0.73 \\
\hline $\mathrm{BA}$ & 35 & $1(2.9)$ & $34(97.1)$ & 0.35 \\
\hline MAS & 30 & $0(0.0)$ & $30(100)$ & 0.99 \\
\hline Others & 28 & $0(00)$ & $28(100)$ & 0.95 \\
\hline
\end{tabular}

Table (4): Relationship of between sex of neonates, gestational age, birth weight and causes of NRD

\begin{tabular}{|c|c|c|c|c|c|}
\hline \multirow[b]{2}{*}{ Causes of RD } & \multirow{2}{*}{$\begin{array}{c}\text { Total } \\
(\mathrm{N}=250)\end{array}$} & \multicolumn{3}{|c|}{ Sex } & \multirow[t]{2}{*}{ P-value } \\
\hline & & \multicolumn{2}{|c|}{$\begin{array}{c}\text { Male (180) } \\
\mathrm{N}(\%)\end{array}$} & $\begin{array}{c}\text { Female (70) } \\
\mathrm{N}(\%)\end{array}$ & \\
\hline RDS & 110 & \multicolumn{2}{|c|}{$90(81.8)$} & $20(18.2)$ & 0.002 \\
\hline TTN & 47 & \multicolumn{2}{|c|}{$28(59.6)$} & $19(40.4)$ & 0.03 \\
\hline$\overline{\mathrm{BA}}$ & 35 & \multicolumn{2}{|c|}{$21(60)$} & $14(40)$ & 0.09 \\
\hline MAS & 30 & \multicolumn{2}{|c|}{ 18(60) } & $12(40)$ & 0.12 \\
\hline Others & 28 & \multicolumn{2}{|c|}{$23(82.1)$} & $5(17.9)$ & 0.211 \\
\hline \multirow[b]{2}{*}{ Causes of RD } & \multirow[b]{2}{*}{$\begin{array}{c}\text { Total } \\
(\mathrm{N}=250)\end{array}$} & \multicolumn{3}{|c|}{ Birth weight } & \multirow[t]{2}{*}{ P-value } \\
\hline & & $\begin{array}{c}<2.5(165) \\
\mathrm{N}(\%) \\
\end{array}$ & $\begin{array}{c}2.5-3.9(74) \\
\mathrm{N}(\%) \\
\end{array}$ & $\begin{array}{l}\geq 4(11) \\
\mathrm{N}(\%)\end{array}$ & \\
\hline RDS & 110 & $80(72.7)$ & $30(27.3)$ & $0(0)$ & 0.04 \\
\hline TTN & 47 & $30(63.8)$ & $15(32)$ & $(2)(4.2)$ & 0.72 \\
\hline $\mathrm{BA}$ & 35 & $20(57.2)$ & $11(31.4)$ & $4(11.4)$ & 0.23 \\
\hline MAS & 30 & $17(56.7)$ & $10(33.3)$ & $3(10)$ & 0.25 \\
\hline Others & 28 & $18(64.3)$ & $8(28.6)$ & $2(7.1)$ & 0.83 \\
\hline \multirow[b]{2}{*}{ Causes of RD } & \multirow[b]{2}{*}{$\begin{array}{c}\text { Total } \\
(\mathrm{N}=250)\end{array}$} & \multicolumn{3}{|c|}{ Gestational age } & \multirow[t]{2}{*}{ P-value } \\
\hline & & $\begin{array}{c}\text { Preterm<3 } \\
7 \mathrm{w}(142) \\
\mathrm{N}(\%) \\
\end{array}$ & $\begin{array}{c}\text { Fullterm 37- } \\
42(92) \\
\mathrm{N}(\%) \\
\end{array}$ & $\begin{array}{c}\text { Postterm } \\
>16(16) \\
\mathrm{N}(\%) \\
\end{array}$ & \\
\hline RDS & 110 & $100(90.9)$ & $10(9.1)$ & $0(0.0)$ & $\mathrm{P}<0.001$ \\
\hline TTN & 47 & $2(4.3)$ & $40(85.1)$ & $5(10.6)$ & $\mathrm{P}<0.001$ \\
\hline $\mathrm{BA}$ & 35 & $15(42.9)$ & $16(45.7)$ & $4(11.4)$ & 0.24 \\
\hline MAS & 30 & $10(33.3)$ & $18(60)$ & $2(6.7)$ & 0.006 \\
\hline Others & 28 & $15(53.6)$ & $8(28.6)$ & $5(17.8)$ & 0.340 \\
\hline
\end{tabular}


Respiratory Distress and Its Outcome among Neonates Admitted to Neonatal Intensive Care Unit of

Table (5):Frequency of causes of NRD and their outcome

\begin{tabular}{|c|c|c|c|c|c|}
\hline \multirow[t]{2}{*}{ Causes } & \multicolumn{3}{|c|}{ Immediate outcome } & \multirow{2}{*}{$\begin{array}{c}\text { Case } \\
\text { fatality } \\
\text { rate }(\%)\end{array}$} & \multirow{2}{*}{$\begin{array}{c}\text { Total } \\
\mathrm{N}=250\end{array}$} \\
\hline & $\begin{array}{l}\text { Cured } \\
\mathrm{N}=101\end{array}$ & $\begin{array}{l}\text { Discharged with } \\
\text { complication } \\
\mathrm{N}=26\end{array}$ & $\begin{array}{c}\text { Died } \\
\mathrm{N}=123\end{array}$ & & \\
\hline RDS & 15 & 5 & 90 & 81.8 & 110 \\
\hline TTN & 47 & 0 & 0 & 0 & 47 \\
\hline Birth asphyxia & 15 & 8 & 12 & 34.3 & 35 \\
\hline MAS & 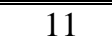 & 2 & 17 & 56.7 & 30 \\
\hline CHD & 0 & 8 & 2 & 20 & 10 \\
\hline Neonatal sepsis & 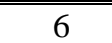 & $\overline{11}$ & $\overline{11}$ & 12.5 & 8 \\
\hline Congenital pneumonia & 6 & 0 & 0 & 0 & 6 \\
\hline Congenital anomalies & $\overline{11}$ & 2 & $\overline{11}$ & 25 & 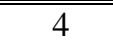 \\
\hline
\end{tabular}

Table (6): Underlying illnesses of NRD in this study, compared with results from previous studies

\begin{tabular}{|c|c|c|c|c|c|c|}
\hline Study & $\begin{array}{l}\text { Current } \\
\text { study }\end{array}$ & $\begin{array}{c}\text { Abdelrah } \\
\text { man et } \\
\text { al., (3) }\end{array}$ & $\begin{array}{l}\text { Tochie et } \\
\text { al., (4) }\end{array}$ & $\begin{array}{l}\text { Rao and } \\
\text { Rao (5) }\end{array}$ & $\begin{array}{c}\text { Abou- } \\
\text { Faddan } \\
\text { and } \\
\text { abdelaziz. } \\
\text { (6) }\end{array}$ & $\begin{array}{c}\text { Rijal and } \\
\text { Shrestha } \\
\text { (7) }\end{array}$ \\
\hline Published year & 2019 & 2014 & 2016 & 2017 & 2018 & 2018 \\
\hline Country & Yemen & Sudan & Cameroon & India & Egypt & Nepal \\
\hline Number of cases & $\begin{array}{c}250 \\
(52.9 \%)\end{array}$ & $\begin{array}{c}100 \\
(56.5 \%)\end{array}$ & $\begin{array}{c}334 \\
(47.5 \%)\end{array}$ & $\begin{array}{c}200 \\
(13.3 \%)\end{array}$ & $\begin{array}{c}487 \\
(52.9 \%)\end{array}$ & $\begin{array}{c}109 \\
(34.3 \%)\end{array}$ \\
\hline RDS & $\begin{array}{c}110 \\
(44 \%)\end{array}$ & $\begin{array}{c}15 \\
(15 \%)\end{array}$ & $\begin{array}{c}47 \\
(14 \%)\end{array}$ & $\begin{array}{c}64 \\
(32 \%)\end{array}$ & $\begin{array}{c}223 \\
(45.8 \%)\end{array}$ & $\begin{array}{c}13 \\
(11.9 \%)\end{array}$ \\
\hline TTN & $\begin{array}{c}47 \\
(18.8 \%)\end{array}$ & $\begin{array}{c}28 \\
(28 \%)\end{array}$ & $\begin{array}{c}83 \\
(25 \%)\end{array}$ & $\begin{array}{c}18 \\
(9 \%)\end{array}$ & $\begin{array}{c}83 \\
(17 \%)\end{array}$ & $\begin{array}{c}17 \\
(15.6 \%)\end{array}$ \\
\hline Birth asphyxia & $\begin{array}{c}35 \\
(14 \%) \\
\end{array}$ & - & $\begin{array}{c}27 \\
(8 \%) \\
\end{array}$ & $\begin{array}{c}37 \\
(18.5 \%) \\
\end{array}$ & - & $\begin{array}{c}13 \\
(11.9 \%) \\
\end{array}$ \\
\hline MAS & $\begin{array}{c}30 \\
(12 \%)\end{array}$ & $6(6 \%)$ & $\begin{array}{c}37 \\
(11 \%)\end{array}$ & $\begin{array}{c}70 \\
(35 \%) \\
\end{array}$ & $\begin{array}{c}9 \\
(1.8 \%) \\
\end{array}$ & $\begin{array}{c}23 \\
(21.1 \%)\end{array}$ \\
\hline \multicolumn{7}{|l|}{ Others } \\
\hline CHD & $\begin{array}{c}10 \\
(4 \%) \\
\end{array}$ & $\begin{array}{c}9 \\
(9 \%) \\
\end{array}$ & 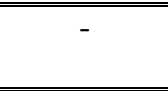 & $\begin{array}{c}7 \\
(3.5 \%) \\
\end{array}$ & - & $\begin{array}{c}7 \\
(6.4 \%) \\
\end{array}$ \\
\hline Neonatal sepsis & $\begin{array}{c}8 \\
(3.2 \%) \\
\end{array}$ & $\begin{array}{c}24 \\
(24 \%) \\
\end{array}$ & $\begin{array}{c}103 \\
(31 \%) \\
\end{array}$ & - & - & $\begin{array}{c}18 \\
6.5 \%) \\
\end{array}$ \\
\hline $\begin{array}{l}\text { Congenital } \\
\text { pneumonia }\end{array}$ & $\begin{array}{c}6 \\
(2.4 \%) \\
\end{array}$ & $\begin{array}{c}18 \\
(18 \%) \\
\end{array}$ & $\begin{array}{c}37 \\
(11 \%) \\
\end{array}$ & $\begin{array}{c}2 \\
(1 \%) \\
\end{array}$ & $\begin{array}{c}86 \\
(17.7 \%) \\
\end{array}$ & $\begin{array}{c}2 \\
(1.8 \%) \\
\end{array}$ \\
\hline Congenital anomalies & $\begin{array}{c}4 \\
(1.6 \%)\end{array}$ & $\begin{array}{c}18 \\
(18 \%)\end{array}$ & $\begin{array}{c}37 \\
(11 \%)\end{array}$ & $\begin{array}{c}2 \\
(1 \%)\end{array}$ & $\begin{array}{c}86 \\
(17.7 \%)\end{array}$ & $\begin{array}{c}2 \\
(1.8 \%)\end{array}$ \\
\hline
\end{tabular}




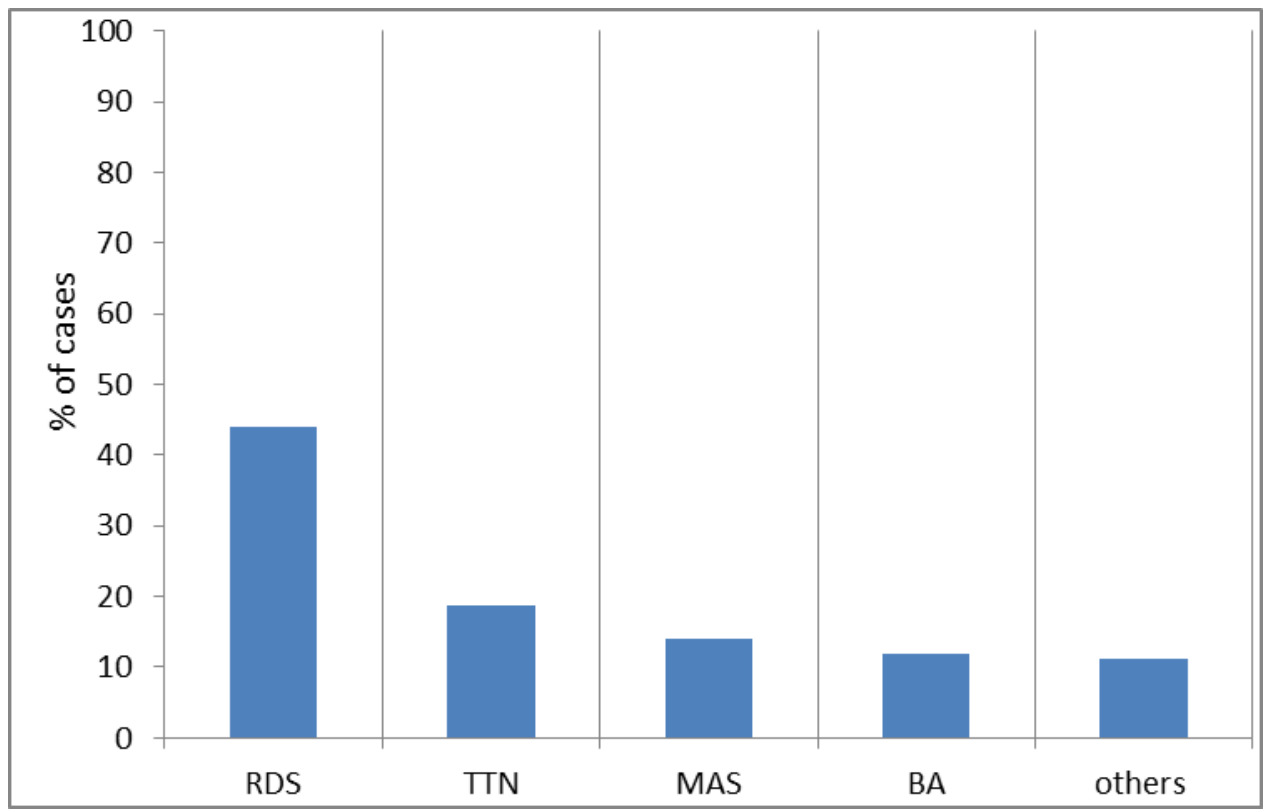

Figure(1): The percentage of cases with NRD

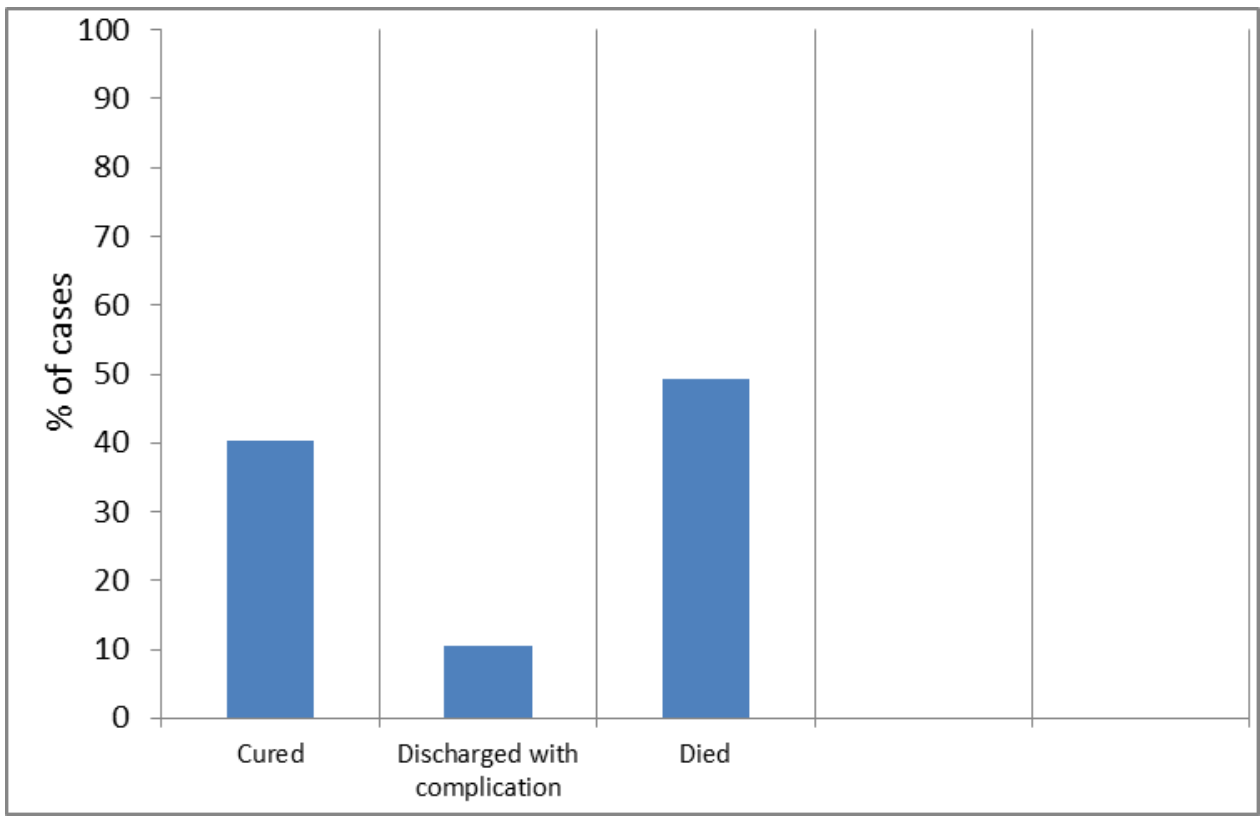

Figure(2): Frequency of immediate outcome of NRD

\section{Discussion}

We had observed that, the most frequent underlying cause for RD in children was RDS $44 \%$ of cases, followed by TTN $18.8 \%$, birth asphyxia $14 \%$, MAS (12\%), others
$11.2 \%$ (CHD 4\%, sepsis 3.2\%, congenital pneumonia $2.4 \%$, and congenital anomalies 1.6\%. Compared to previous studies [3-7], our results showed some similarities and 
differences. This wide variation in proportion of causes of respiratory distress among various studies may be due to antenatal care in that community, availability of obstetricians including trained birth attendants, use of preventive measures during antenatal period, proportion of term and preterm deliveries, non-uniform inclusion criteria, various other factors such as status of community and type of facilities in institution [18]. The first important cause of respiratory distress in this study was RDS, which was found to be 110(44\%). Similarly, RDS was found to be the first cause of respiratory distress with an proportion of $45.8 \%$ by Abou-Faddan and Abdelaziz [6] and Sabzehei et al., (36.6\%) [19]. low proportion were found by Rijal and Shrestha (11.9\%) [7], abdulrahaman et al., (15\%) [3] and Tochie et al., (14\%) [4] .This can be explained by a higher proportion of neonates in our study were premature. In the current study, it was observed that cesarean delivery was significantly higher in RDS $(77.3 \%$ versus $22.7 \%$ for babies with normal vaginal delivery, $\mathrm{p}=0.04)$. This is in agreement with the results of other studies [7,20,21]. Neonates born by cesarean section have a larger residual volume of lung fluid, secrete less surfactant to the alveolar surface and have a delayed clearance of lung fluid[22]; thus, they are at higher risk of developing RDS. Male babies had higher rates of RD in RDS $(81.8 \%$ versus $18.2 \%$ for females, $\mathrm{p}=0.002)$. This is consistent with several studies [20,21]. Differences in hormonal regulation of lung development provide candidate mechanisms to account for an increased risk of RDS associated with male sex [23]. Androgens delay lung fibroblast secretion of fibroblast pneumocyte factor, which can delay the development of alveolar type II cells; furthermore, they reduce the release of surfactant. On the contrary, estrogens promote the synthesis of surfactant, including phospholipids, lecithin and surfactant proteins $\mathrm{A}$ and $\mathrm{B}$, and improve fetal lung development by increasing the number of alveolar type II cells and the synthesis of lamellar bodies[24].

In the current study, it was observed that prematurity was significantly higher in RDS (90.9\% versus $9.1 \%$ for babies with term, $\mathrm{p}<0.001)$. This is in agreement with the results of other studies [6,7,20,21] .Respiratory distress syndrome (RDS) occurs primarily in premature infants; its incidence is inversely related to gestational age and birth weight. Surfactant deficiency (decreased production and secretion) is the primary cause of RDS [12]. In the current study, it was also observed that low birth weight was significantly higher in RDS (72.7\% versus $27.3 \%$ for babies with normal weight , $p=0.04)[6,7,20]$. The premature and low-birth-weight neonates usually have pulmonary immaturity and limited respiratory muscle strength. It is important to make a diagnosis and find the etiology to provide appropriate management to prevent preterm delivery [24]. Transient tachypnea of newborn was the second most common cause of respiratory distress found in $47(18.8 \%$ ) with similar proportion as reported by other 
studies [6,7]. But, kommawar et al., found TTN was the most common cause of respiratory distress in newborns with proportion of $40 \%$.[25]. In the study done by Sodawat et al., a transient tachypnea of newborn was found to be the commonest of respiratory distress in newborns with incidence of $(32.6 \%)$ [18].

In the current study, it was observed that cesarean delivery was significantly higher in TTN (57.4\% versus $42.6 \%$ for babies with normal vaginal delivery, $\mathrm{p}=0.02)$. This is consistent with previously reported findings $[7,26]$. These have been attributed to delayed or abnormal fetal lung fluid clearance due to the absence of the hormonal changes that accompany spontaneous labor [27]. Transient tachypnea of newborn is believed to be secondary to slow absorption of fetal lung fluid, resulting in decreased pulmonary compliance and tidal volume and increased dead space [13]. It was also observed that prolonged labor was significantly higher in TTN $(53.2 \%$ versus $46.8 \%$ for babies with normal labor, $\mathrm{p}=0.006$ ), which is consistent with other results $[26,27,28]$. Prolonged labor may cause dysfunctional catecholamine regulation, mild pulmonary capillary leak and myocardial dysfunction [28]. In the current study, it was observed that male gender was significantly higher in TTN $(59.6 \%$ versus $40.4 \%$ for female, $\mathrm{p}=0.03$ ). This is in agreement with the results of other studies $[26,27]$. It was also observed that full term was significantly higher in TTN, which is consistent with other results [6,26]. Birth asphyxia constituted $35(14 \%)$ of the total respiratory distress cases in our study. A proportion of birth asphyxia of $12.2 \%$ and $11.9 \%$ were found by konmnawar et al., [25] and Rijal and Shrestha [7] respectively. Very low proportion were found by Sabzehei et al., $(1.1 \%)[19]$. It was observed that prolonged labor was significantly higher in BA $(85.7 \%$ versus $14.3 \%$ for babies with normal labor, $\mathrm{P}=0.03$ ). This was agreement with other studies [29,30].It is clear that when labor is prolonged, there is a high probability for the fetus to become distressed[31] Meconium aspiration syndrome constituted $30(12 \%)$ of the total respiratory distress cases in our study. Proportion of MAS of $9.3 \%$ and $11 \%$ were found by Sodawat et al., [18] and Tochie et al. [4] respectively. Very high proportions were found by Rao and Rao (35 $\%$ ) [5]. It was observed that prolonged labor was significantly higher in MAS $(86.7 \%$ versus $13.3 \%$ for babies with normal, $\mathrm{p}=0.04)$. This is consistent with previously reported findings [32,33]. Probably because this is the referral hospital catering more than $250 \mathrm{~km}$ radial distance hence the referred patient took longer time to reach the hospital. It was also observed that full term was significantly higher in MAS, which is consistent with other results [33,34]. This was related to maturity and increased levels of intestinal hormone, motilin with increasing gestational age [34]. The immediate outcome of NRD is cure in $40.4 \%$, patients discharged with complications are $10.4 \%$ and death occurred in $49.2 \%$ of cases. In a study done by Abdelrahman et al.,[3] the immediate outcome of NRD is cure in $56 \%$, patients 
discharged with complications are $8 \%$ and death occurred in $36 \%$ of cases. Sabzehei et al., [19] reported that 19.3 of infants with NRD died of the disease. Sodawat et al., [18] found that overall death among cases of respiratory distress was $28 \%$. But, Rao and Rao [5] found a very low death rate among NRD (2.5\%). Comparison between the causes and their fatalities in this study revealed that hyaline membrane disease has case fatality rate of (81.8) followed by MAS $(56.7 \%)$ and BA $(34.3 \%)$. This result is consistence with other studies $[5,6,10]$. In a study done by Sodawat et al., the fatality rate were $47.58 \%$ for RDS, $42.24 \%$ for sepsis, $35.71 \%$ for MAS, $35.55 \%$ for HIE and $33.33 \%$ for cases of CHD[18]. Kommawar et al.,[25] reported the highest case fatality rate were $61.6 \%$ for $\mathrm{HMD}, 17.4 \%$ for $\mathrm{BA}$ and $8.13 \%$ for MAS. The high fatality rate can be explained by the higher percentages of preterm and LBW, inadequate antenatal care, less use of steroid in prematurity antenatal, less meticulous management of high risk pregnancies. In addition to our study was conducted in children hospital, which represents the reference hospital for neonates of high risk pregnancies and complicated deliveries and lack of surfactant replacement therapy in our hospital and mechanical ventilation. In conclusions respiratory distress was the major cause of admission in our NICU. The most common causes of respiratory distress were RDS, perinatal asphyxia, and MAS. The common cause of death was RSD. RDS is significantly correlated with cesarean section, prematurity, male sex and low birth weight, while prolonged labor were significantly associated with TTN, BA and MAS. From this study we may recommend the followings; early detection and appropriate management of risk factor is essential to ensure better outcome in all infants presenting with respiratory distress. Good antenatal care with prompt management of high risk pregnancies. Early recognition of potential risk factors for respiratory distress will be helpful in decreasing the burden associated with neonatal respiratory distress.

Proper training of physicians in the management of neonatal respiratory distress, including availability of equipped NICU with ventilator and surfactant facilities.

\section{Conflict of interest}

The research protocol and the questionnaires were conducted according to principles of the Declaration of Helsinki, as well as reviewed and approved by the college ethical research committee. Verbal consents were also taken from the parents and caregivers of children involved in the study.

\section{References}

[1]Swarnakar K, Swarnakar M. Neonatal respiratory distress in early neonatal period and its outcome. Int $\mathrm{J}$ Biomed Adv Res 2015;6(9):643-7.

[2]Zaazou MH, Kamal MM, Ali RM, ElHussieny NA, El-Sayed M. Descriptive study of cases of respiratory distress in NICU in Ahmed Maher teaching hospital. Med J Cairo Univ 2011;79(1): 441-48.

[3]Abdelrahman SMK, Hamed SMA, Nasr

A. Neonatal respiratory distress in 
Respiratory Distress and Its Outcome among Neonates Admitted to Neonatal Intensive Care Unit of

Mukalla Maternity and Child Hospital, Yemen

Omdurman Maternity Hospital, Sudan. Sudan J Paediatr 2014; 14(1):65-70.

[4]Tochie J N, Choukem SP, Langmia R N, Barla E, Koki-Ndombo P. Neonatal respiratory distress in a reference neonatal unit in Cameroon: an analysis of prevalence, predictors, etiologies and outcomes. Pan African Medical Journal 2016; 24:152.

[5]Rao GC, Rao MSP. Etiological profile of respiratory distress in first day of life of a newborn baby. Int J Contemp Pediatr 2017; 4(1):210-4.

[6]Abou-Faddan $\mathrm{HH}$ and Abdelaziz NH. Respiratory Distress and Its Outcome among Neonates Admitted to Neonatal Intensive Care Unit of Assiut University Children Hospital, Egypt. The Egyptian Journal of Community Medicine 2018; 36 (2): 69-78. [7]Rijal P, Shrestha M. Scenario of Neonatal Respiratory Distress in Tertiary Hospital. J Nepal Health Res Counc 2018;16(39):131-5. [8]Ahlfeld SK. Respiratory tract disorders. In Nelson Textbook of Pediatrics (21th ed). KliegmanRM, Geme JW, Blum NJ, Shah SS, Tasker RC, Wilson KM, Behrman RE (eds), W. B Saunders company, 2019; chapter 122, pp3987-3988.

[9]Bak SY, Shin YH, Jeon JH, et al. Prognostic factors for treatment outcomes in transient tachypnea of the newborn. Pediatr Int 2012;54(6):875-880.

[10]Mehta A, Pratap D, Kushwaha K.P, Singh A, Sharma B, Mittal M. A study of causes of respiratory distress in neonates presenting within 72 hours. J Pediatr Res 2017;4(01):24-30.
[11]Reuter S, Moser C, Baack M. Respiratory Distress in the Newborn. Pediatrics in Review 2014;35(10):417-429. [12]Ahlfeld SK. Respiratory Distress Syndrome(Hyaline Membrane Disease). In Nelson Textbook of Pediatrics (21th ed). Kliegman RM, Geme JW, Blum NJ, Shah SS, Tasker RC, Wilson KM, Behrman RE (eds), W. B Saunders company, 2019; chapter 122.3, pp 3997-4018.

[13]Ahlfeld SK. Transient Tachypnea of the Newborn. In Nelson Textbook of Pediatrics (21th ed). KliegmanRM, Geme JW, Blum NJ, Shah SS, Tasker RC, Wilson KM, Behrman RE (eds), W. B Saunders company, 2019; chapter 122.6, pp 4043-4044.

[14]Golubnitschaja O, Yeghiazaryan K, Cebioglu M, Morelli M, Herrera Marschitz M. Birth asphyxia as the major complication in newborns: Moving towards improved individual outcomes by prediction, targeted prevention and tailored medical care. EPMA J 2011;2(2):197 210.

[15]Greenough A, Murthy V, Milner AD. Respiratory Disorders in the newborn. In: Wilmott RW, Chernick V, Boat TF, Deterding RR, Bush A, Ratjen F, editors. Kendig and Chernick's Disorders of the Respiratory tracts in Children. 8th ed. Philadelphia: Saunders Elsevier; 2012. p. 358 85.

[16]Arnon S, Litmanovitz I. Diagnostic tests in neonatal sepsis. Curr Opin Infect Dis 2008;21(3): 2237.

[17]Rajab A. M .and .Ghareba A. M. Neonatal Mortality Rate in the Special Care Baby Unit (SCBU) at Gharian Teaching 
Respiratory Distress and Its Outcome among Neonates Admitted to Neonatal Intensive Care Unit of

Mukalla Maternity and Child Hospital, Yemen

Hospital. Journal of Medical Science and Clinical Research 2013.1(5) 195-208.

[18]Sodawat R, Singh C, Garg P, Sharma P. Clinico-epidemiological study of respiratory distress in newborn and associated risk factors. Int J Contemp Pediatr 2018;5(4):1576-82.

[19]Sabzehei MK, Basiri B, Shokouhi M, Fayyazi A. Causes and Outcomes of Respiratory Distress in Y. Neonates Hospitalized in NICU of Be'sat Hospital in Hamadan Province, Iran. Int J Pediatr 2017; 5(12): 6253-60.

[20]Condo V, Cipriani S, Colnaghi M, Bellu R, Zanini R, Bulfoni C, Parazzini F, Mosca F. Neonatal respiratory distress syndrome: are risk factors the same in preterm and term infants?.J Matern Fetal Neonatal Med 2017; 30(11):1267-1272.

[21]QariL SA, Alsufyani AA, Muathin SH , El Margoushy NM . Prevalence of Respiratory Distress Syndrome in Neonates, The Egyptian Journal of Hospital Medicine 2018;70 (2): 257-264.

[22]Ramachandrappa A, Jain L. Elective cesarean section: its impact on neonatal respiratory outcome. Clin Perinatol. 2008; 35(2): 373-93.

[23]Seaborn T, Simard M, Provost PR, Piedboeuf B, Tremblay Sex hormone metabolism in lung development and maturation. Trends Endocrinol Metab 2010; 21(12):729-38.

[24]Wayessa Z, Belachew T, Joseph J. Birth asphyxia and associated factors among newborns delivered in Jimma zone public hospitals, Southwest Ethiopia: A cross- sectional study. Journal of Midwifery and Reproductive Health 2018; 6(2): 1289-1295. [25]Kommawar A, Borkar R, Vagha J, Lakhkar B, Meshram R, Taksandae A. Study of respiratory distress in newborn. Int $\mathrm{J}$ Contemp Pediatr 2017;4(2):490-4.

[26]Hamdoon GW. Risk factors for development of transient tachypnea of newborns. Ann Coll Med Mosul 2018; 40 (1): 15-19).

[27]Chiluka S, Srinivas M, Anitha K, Basha $\mathrm{S}$, Reddy P. Incidence, clinical profile and outcome of transient tachypnea of newborn. Int J Pediatr Res 2017;4(10):623-628.

[28]Tutdibi E, Gries K, Bucheler M, Misselwitz B, Schlosser RL, Gortner L. Impact of labor on outcomes in transient tachypnea of the newborn: population based study. Pediatrics 2010; 125(3): 577-583.

[29]Torres-Munoz J, Rojas C, MendozaUrbano D, Marin-Cuero D, Orobio S, Echandia C. Risk factors associated with the development of perinatal asphyxia in neonates at the Hospital Universitario del Valle, Cali, Colombia, 2010-2011.Biomedica 2017.; 37:51-6.

[30]Gebreheat G, Tsegay T, Kiros D, Teame H, Etsay N, Welu G, Abraha D Prevalence and Associated Factors of Perinatal Asphyxia among Neonates in General Hospitals of Tigray, Ethiopia, 2018. Biomed Res Int 2018:5351010.

[31]Wosenu L, Worku AG, Teshome DF, Gelagay AA. Determinants of birth asphyxia among live birth newborns in University of Gondar referral hospital, northwest Ethiopia: 
A case-control study. PLoS One 2018 ;13(9):e0203763.

[32]Rovas L, Razbadauskas A, Boguziene E. Risk factors that can lead to development of meconium aspiration syndrome. Obstet Gynecol Int J 2018;9(3):208-212.

[33]Kamble MB, Jain P. Meconium aspiration syndrome: clinical profile, risk factors and outcome in central India. Int $\mathbf{J}$ Contemp Pediatr 2019;6(1):144-9.

[34]Phirke DS, Shah B, Ranee D. A study of the probable risk factors for meconium aspiration syndrome. Med Pulse International Journal of Pediatrics 2017; 3(1): 12-15. 